\title{
IDENTIFICATION OF INTERSPECIFIC POTATO HYBRIDS WITH COMBINED RESISTANCE TO LATE BLIGHT (PHYTOPHTHORA INFESTANS) AND NEMATODE (GLOBODERA ROSTOCHIENSIS)
}

\author{
Nadezhda Zoteyeva ${ }^{1, \#}$, Guna Sprūde ${ }^{2}$, Natalia Klimenko ${ }^{1}$, and leva Mežaka ${ }^{2}$ \\ ${ }^{1}$ N. I. Vavilov Institute of Plant Genetic Resources, 42 B. Morskaya Str., St. Petersburg, RUSSIA; nzoteyeva@ gmail.com \\ 2 Institute for Agricultural Resources and Economics, 2 Zinātnes iela Str., Priekuḷu pag., Priekuḷu nov., LV-4126, LATVIA \\ \# Corresponding author, nzoteyeva@gmail.com
}

Communicated by Ilze Skrabule

\begin{abstract}
Late blight (agent Phytophthora infestans) and potato cyst nematode (PCN) caused by Globodera rostochiensis are economically important pathogens, which may significantly reduce potato yields. In this study interspecific potato hybrids were used as a source of resistance for combined resistance to economically important potato pathogens: late blight and cyst nematode. The aim of our study was to identify hybrid progenies with combined resistance to both pathogens and to verify the applicability of several molecular markers associated with resistance to G. rostochiensis pathotype Ro1 to identify resistant plants. Ninety-two clones of eleven original interspecific potato hybrids obtained in crosses with the cultivated S. tuberosum group tuberosum, S. tuberosum group Andigena, S. tuberosum group Phureja and wild S. guerreroense, S. microdontum, $\mathrm{S}$. kurtzianum, S. neoantipoviczii and S. tarijense potato species were screened in bioassays and by molecular markers. PCN resistant or moderately resistant clones were found among the progenies of nine hybrids. Results were highly correlated with resistance status detected by molecular markers linked to the $\mathrm{H} 1$ (marker 57R) and Gro1-4 (marker Gro1) genes. Marker CP113 (linked to the $\mathrm{H} 1$ gene) was not polymorphic and failed to detect resistance status. Combination of foliar late blight resistance and resistance to PCN was identified in hybrids obtained in crosses with plants of species S. microdontum, S. tarijense and S. phureja and in the hybrid between $\mathrm{S}$. guerreroense and Black's P. infestans race differential carrying gene R-5.
\end{abstract}

Key words: Solanum L., marker assisted selection, host plant resistance, late blight, nematode.

\section{INTRODUCTION}

Improvement of resistance to economically important diseases and pests in current potato cultivars is one of the main goals of breeding programmes worldwide. Late blight (agent Phytophtora infestans) and potato cyst nematode (Globodera rostochiensis) can both reduce yields by up to 50\% (Marks and Brodie, 1998; Fry, 2008; Guha and Grünwald, 2014). The International Potato Centre has demonstrated that potato farmers in Peru benefit USD 130 per ha and have a $26 \%$ return of investment rate by increasing tuber yield by $9 \%$ and by the reduction of fungicide application due to growing late blight resistant cultivars (Sevilla and Ortiz, 2010). Resistance to nematodes is one of the mostly desirable traits in newly developed potato cultivars. Currently, potato breeding requires basic material with re- sistance to two and more pathogens. Solanum L. species are intensively utilised in potato breeding as sources of resistance to many diseases and pests. Resistance genes from wild relative species have been incorporated into the genotypes of a number of potato varieties (Glendinninger, 1983; Ross, 1986; Flis et al., 2005; Aversano et al., 2007; Chimote et al., 2008).

Infection with the potato cyst nematode (PCN) can also lead to severe decline in potato yield wherever potato is grown. The most common pathotype of $G$. rostochiensis in the North-Western zone of Europe where Russian Federation and Latvia are situated is Ro1 (Holgado and Magnusson, 2010). In the United Kingdom, Ro1 also essentially predominates (Bradshaw and Ramsay, 2005). 
The necessity to grow nematode resistant varieties limits variety choice. Resistance to $G$. rostochiensis has been found in Solanum species (Dalamu et al., 2012) and it is obligatory for registrations of new potato varieties (Galek et al., 2011). Several loci conferring resistance to PCN have been identified with either partial (Gro1.2, Grol.3, Grol.4, Grpl) or nearly-full (H1, Grol, GroIV) resistance (FinkersTomczak et al. 2011). Breeders are working to develop nematode resistant cultivars, but the number of cultivars available is still limited. A large, genetically diverse gene pool has to be used in hybridisation to achieve success, as $S$. tuberosum has a narrow source of resistance genes (Sudha et al. 2016). In most of the recently released potato varieties, resistance against $G$. rostochiensis pathotype Ro1 is ensured by the $\mathrm{Hl}$ gene, which is localised on potato chromosome V (Gebhardt et al., 1993; Bakker et al., 2004; Paal et al., 2004; Park et al. 2018). Use of species related to cultivated potato offers the possibility to enlarge the gene pool for pest and disease resistance. Worldwide breeders achieved success in producing potato varieties resistant to $G$. rostochiensis by introducing the $H 1$ gene. However, widespread and extensive use of varieties with $H \mathrm{l}$ has caused a rapid worldwide increase in G. pallida (Bradshaw et al., 1998; Bryan et al., 2002). Currently, breeding is focused on development of varieties resistant to a broad spectrum of PCN populations. The DNA marker Grol can identify the Grol-4 gene (Gebhardt et al., 2006). Grol-4 confers nearly absolute resistance to all G. rostochiensis pathotypes and is considered as a useful resistance gene (Baron et al., 1990; Paal et al., 2004).

Marker assisted selection has become an important tool for crop improvement utilising hybrid breeding or pyramiding of genes for resistance to different harmful organisms. Nevertheless, bioassays are still the basic approach to select resistant plants (Yu et al., 2000; Park et al. 2018). The crucial point in identification of resistant hybrids by MAS is the concordance of the resistance status detected by DNA markers and bioassays. Reliability of marker 57R has been validated in several studies - Schultz at al. (2012) found almost perfect concurrence with only one exception in Australian and Scottish breeding material, Milzarek et al. (2014) has found $93.7 \%$ agreement between both tests in Młochów Research Centre material, but Park et al. (2018) found $91.5 \%$ match in the New York breeding programme. Recently, hybrid progenies derived from $S$. tuberosum L., $S$. tuberosum Group Andigena and S. tuberosum Group Phureja have provided insight on the evolution of the $H I$ locus Finkers-Tomczak et al. (2011).

In this study, interspecific potato hybrids of different genetic backgrounds were assessed for resistance to cyst nematode pathotype Ro1 and to late blight. Late blight resistance was assessed by bioassays, and PCN was screened both by bioassays and available molecular markers- CP113 and 57R linked to the gene $H 1$ conferring resistance to $G$. rostohiensis pathotype Ro1 and marker Gro1 linked to resistance to Gro1-4.

The aim of the present study was to validate the molecular markers CP113, 57R and Gro1-4 for identification of PCN resistant hybrids and to identify those with combined resistance to late blight and to Globodera rostochienses.

\section{MATERIAL AND METHODS}

Plant material. Interspecific hybrids evaluated were obtained in crosses using the parental accessions mentioned in Table 1 .

Evaluation was performed on a set of the following potato hybrids: grr $\times$ B.d.R5, grr $\times \operatorname{adg}$, $($ grr $\times \operatorname{adg}) \times$ cv. Omega, nan $\times$ phu-1, nan $\times($ tub $\times$ phu- 2$)$, nan $\times$ AU, mcd $\times$ tar, $($ mcd $\times$ tar $) \times \mathrm{ktz}, \mathrm{AU} \times \mathrm{rzc}$, tub $\times$ phu -2 and $(\mathrm{AU} \times \mathrm{tub}) \times$ phu-2. Some hybrids and the parental accessions were previously evaluated for foliar or tuber resistance to late blight. Hybrid populations included in the current research were newly obtained from seeds.

Table 1. Parental accessions of the evaluated potato interspecific hybrids

\begin{tabular}{|c|c|c|c|c|c|c|}
\hline \multirow[t]{2}{*}{ Species } & \multirow{2}{*}{$\begin{array}{c}\text { Abbrevation } \\
\text { of the species* }\end{array}$} & \multirow{2}{*}{$\begin{array}{l}\text { No. in VIR } \\
\text { catalogue }\end{array}$} & \multirow{2}{*}{$\begin{array}{c}\text { Inventory No in other } \\
\text { collections }\end{array}$} & \multicolumn{2}{|c|}{ Resistance to late blight } & \multirow[t]{2}{*}{ References } \\
\hline & & & & foliar & tuber & \\
\hline S. guerreroense Corr. & grr & 18407 & USA, PI 161727 & $\mathrm{R}$ & n.t. $* *$ & Zoteyeva et al., 2012 \\
\hline S. kurtzianum Bitt. et Wittm. & ktz & 12488 & $\begin{array}{l}\text { Argentina, OKA 4964; } \\
\text { ŃŲ, PI } 472938\end{array}$ & $\mathrm{~S}$ & $\mathrm{R}$ & Zoteyeva, 2000 \\
\hline S. tarijense Hawkes & $\operatorname{trj}$ & 10712 & USA, PI 473336 & PR & n.t. & Zoteyeva et al., 2012 \\
\hline S. ruiz-ceballosii Card. & $\mathrm{rzc}$ & 7370 & Bolivia, Horlahon, 8664 & $\mathrm{R}$ & PR & Zoteyeva et al., 2012 \\
\hline $\begin{array}{l}\text { Selection from } S \text {. tuberosum } \\
\text { Group. Andigena Hawkes }\end{array}$ & $\operatorname{adg}$ & 8077 & - & $\mathrm{S}$ & $\mathrm{R}$ & Zoteyeva, 2014 \\
\hline S. phureja Juz. et Buk.-2 & phu & unknown & - & $\mathrm{R}$ & PR & Zoteyeva, no published data \\
\hline S. phureja- Juz. et Buk-1 & phu & - & USA PI 320358 & S & n.t. & Zoteyeva, no published data \\
\hline
\end{tabular}

* species abbreviation acc. to the Centre for Genetic Resources, Wageningen, The Netherlands.

** n.t., not tested. 
Phenotyping. Foliar late blight resistance assay. Resistance was assessed in leaflet tests using the isolate (virulence genes 1.2.3.4.6.7.11.12.) sampled from local populations of $P$. infestans. The genotypes of Black's differential set offered by IHAR-Mlochow (Poland) each carrying a single R-gene $(R I-R 11)$ were applied to identify $P$. infestans genes for virulence.

Detached leaflets collected from plants grown in a greenhouse were sampled from the mid part of plants. Three leaflets detached from each plant in two replications were drop inoculated. Inoculum concentration comprised 20000 sporangia $/ \mathrm{ml}$. Leaflets of susceptible var. Brasla were used as a susceptible and of an accession of S. guerreroense (grr) as resistant controls. Disease was scored using a 1-9 grade scale, where 9 indicated lack of disease symptoms and grade 1 reflected $90-100 \%$ of diseased area (Zarzycka, 2001).

Pot-plant nematode resistance assay. Tubers were planted in $10 \mathrm{~cm}$ diameter pots in a greenhouse with soil infected with cysts of Globodera rostochiensis of pathotype Ro1 according to Stelter (1971). Inoculation was carried out in May and after 8-11 weeks the infection rate was determined and the susceptible clones were identified. Genotypes were designated as resistant if there were no cysts found in any of the replicates. If one to three cysts were found in one to two replicates, the clone was considered to be moderately resistant, clones with 4-5 cysts were rated as moderately susceptible and clones with more than 5 cysts as susceptible. The revealed symptoms were compared with those of the resistant cultivar 'Brasla' and susceptible cultivar 'Mutagenagrie'.

PCR marker assay. Extraction of genomic DNA. Genomic DNA of parents and F1 hybrids was extracted from leaf material following the protocol of Wulff et al. (2002). DNA was extracted from fresh leaves of pot-grown plants. Collected leaves were stored at $-20{ }^{\circ} \mathrm{C}$ until DNA extraction. Approximately $80 \mathrm{mg}$ of leaf tissue per genotype were used for DNA extraction. PCR amplification. The $H 1$ gene for resistance to Globodera rostochiensis was tested with flanking molecular markers CP113 (Skupinová et al. (2002) and 57 R (Finkers-Tomczak, 2011) and the Grol-4 gene was accessed by locus Grol (Gebhard et al., 2006). The resistant allele for resistance to root cyst nematode Rol pathotype was detected by marker CP113 according to a protocol adapted from Skupinovi et al. (2002). The forward primer was 5'- GCG TTA CAG TCG CCG TAT-3' and reverse primer was 5'-GTT GAA GAA ATA TGG AAT CAA A-3'. The marker CP113 was amplified in $20 \mu$ l total volume of $2.5 \mathrm{mM} \mathrm{MgCl}, 0.2 \mathrm{mM}$ dNTPs, primers at concentration $0.3 \mathrm{mM}$ each and $0.65 \mathrm{U}$ Taq polymerase. Cycling conditions were $93{ }^{\circ} \mathrm{C}$ for $180 \mathrm{~s}$ followed by 35 cycles of $93{ }^{\circ} \mathrm{C}$ for $30 \mathrm{~s}, 51{ }^{\circ} \mathrm{C}$ for $45 \mathrm{~s}, 72^{\circ} \mathrm{C}$ for $90 \mathrm{~s}$ and finally $70{ }^{\circ} \mathrm{C}$ for $\left.90 \mathrm{~s}\right)$. The Grol-4 resistance gene was screened by the SCAR marker Grol as described by Gebhardt et al. (2006). The forward primer was 5'-TCT TTG GAG ATA CTG ATT CTC A-3' and the reverse primer was 5'-CGA CCT AAA ATG AAA AGC ATC T-3'. PCR was per- formed in $20 \mu \mathrm{l}$ of $2.5 \mathrm{mM} \mathrm{MgCl}_{2}, 0.2 \mathrm{mM}$ dNTPs, primers at concentration $0.4 \mathrm{mM}$ each and $1 \mathrm{U}$ of Taq polymerase. The PCR parameters for amplification were: $94{ }^{\circ} \mathrm{C}$ for $180 \mathrm{~s}$, 35 cycles of $92{ }^{\circ} \mathrm{C}$ for $20 \mathrm{~s}, 48{ }^{\circ} \mathrm{C}$ for $20 \mathrm{~s}, 72{ }^{\circ} \mathrm{C}$ for $50 \mathrm{~s}$ and final extension of $72{ }^{\circ} \mathrm{C}$ for $10 \mathrm{~min}$. Amplification products were resolved on $1 \%$ agarose $1 \mathrm{x}$ TBE buffer gels $\left(\mathrm{w} \cdot \mathrm{v}^{-1}\right)$ and were visualised by ethidium bromide staining. Individuals were declared resistant, if an amplification product was present and was $760 \mathrm{bp}$ for marker CP113 and 602 bp for marker Gro1. Marker 57R was amplified as described by (Finkers-Tomczak, 2011) with primer sequences 57R_F: TGCCTGCCTCTCCGATTTCT and 57R_R: GGTTCAGCAAAAGCAAGGACGTG. The PCR parameters for amplification were: $95{ }^{\circ} \mathrm{C}$ for $10 \mathrm{~min}, 30$ cycles of $95{ }^{\circ} \mathrm{C}$ for $45 \mathrm{~s}, 63^{\circ} \mathrm{C}$ for $45 \mathrm{~s}, 72{ }^{\circ} \mathrm{C}$ for $45 \mathrm{~s}$ and final extension of $72{ }^{\circ} \mathrm{C}$ for $10 \mathrm{~min}$. In resistant genotypes $450 \mathrm{bp}$ product was amplified.

\section{RESULTS}

Phenotypic evaluation. Clones obtained from individual seedlings were assayed phenotypically and in molecular tests. The results obtained by PCR and biological tests are presented in Table 2. Hybrid progenies derived from the accessions of Mexican (S. guerreroense, S. neoantipoviczii) and Bolivian (S. ruiz-ceballosii, S. microdontum) wild potato species with high foliar late blight resistance (Table 1) were screened in leaflet tests using the aggressive isolate of $P$. infestans and in pot-plant bioassay for resistance to nematode.

The majority of tested plants expressed resistance to late blight and to a smaller extent to pathotype Ro1 nematodes. Resistance levels to both pathogens are shown for the progeny of each hybrid in Table 2 . In populations completely resistant to late blight grr $\times$ adg, nan $\times$ phu- 1 and nan $\times($ tub $\times$ phu-2), only one plant of hybrid nan $\times($ tub $\times$ phu-2) expressed nematode resistance. In the population of hybrid grr $\times$ B.d. $R 5$, half of the plants resistant to late blight were resistant or moderately resistant to nematode (Table 2). Hybrids of population Aurora $\times(\mathrm{tub} \times$ phu- 2$)$ were segregating for resistance to both pathogens - five of 15 clones were resistant and six moderately resistant to late blight and two clones were resistant and four moderately resistant to nematode. Resistance to both pathogens in this population was expressed in only three plants (Table 2). Among five tested progenies of hybrid nan $\times \mathrm{cv}$. Aurora, two combined resistance to late blight and nematode. One late blight resistant clone was moderately susceptible to nematode. Two late blight susceptible clones included nematode susceptible and moderately susceptible phenotypes.

Both tested clones of hybrid $(\operatorname{grr} \times \mathrm{adg}) \times \mathrm{cv}$. Omega were late blight resistant and one of them was resistant to nematode. Combined resistance to both pathogens was found in all three tested clones of mcd $\times$ tar. Among three tested clones of $(\operatorname{mcd} \times \operatorname{tar}) \times \mathrm{ktz}$, two with resistance to late blight were also resistant to nematode and one was susceptible to both pathogens. Among the two tested clones of 
Table 2. Resistance to late blight and response to Globodera rostohiensis of pathotype rol of interspecific potato hybrids with /without markers cp113, gro1-4 and 57r

\begin{tabular}{|c|c|c|c|c|c|c|c|c|c|c|}
\hline \multirow[t]{2}{*}{ Accession } & \multicolumn{10}{|c|}{ Number of plants } \\
\hline & \multicolumn{3}{|c|}{$\begin{array}{c}\text { late blight phenotype resistance } \\
\text { rating: }\end{array}$} & \multicolumn{4}{|c|}{ nematode phenotype resistance rating: } & \multicolumn{3}{|c|}{ with haplotype: } \\
\hline $\operatorname{grr} \times \operatorname{adg}$ & 24 & 0 & 0 & 0 & 0 & 0 & 24 & 24 & 0 & 0 \\
\hline \multirow{4}{*}{ grr $\times$ B.d. $R 5$} & 6 & - & - & 6 & - & - & - & 6 & n.t. & 6 \\
\hline & 2 & - & - & - & 2 & - & - & 2 & n.t. & 2 \\
\hline & 3 & - & - & - & - & 3 & - & 3 & n.t. & 3 \\
\hline & 6 & - & - & - & - & - & 6 & 6 & n.t. & 3 \\
\hline \multirow[t]{3}{*}{ Aurora $\times($ tub $\times$ phu- 2$)$} & 1 & 1 & - & 2 & - & - & - & 2 & n.t. & 2 \\
\hline & 2 & 1 & 1 & - & 4 & - & - & 4 & n.t. & 4 \\
\hline & 2 & 4 & 3 & - & - & - & 9 & 9 & 0 & 0 \\
\hline$($ grr $\times$ adg $) \times$ cv. Omega & 1 & - & - & 1 & - & - & - & 1 & n.t. & 1 \\
\hline \multirow[t]{2}{*}{ nan $\times($ tub $\times$ phu- 2$)$} & 1 & - & - & 1 & - & - & - & 1 & n.t. & 1 \\
\hline & 6 & - & 3 & - & - & - & 9 & 9 & n.t. & 0 \\
\hline \multirow[t]{3}{*}{ nan $\times$ Aurora } & 2 & - & - & 2 & - & - & - & 2 & 2 & n.t. \\
\hline & 1 & - & 1 & - & - & 2 & - & 2 & 2 & n.t. \\
\hline & - & - & 1 & - & - & - & 1 & 1 & 0 & n.t. \\
\hline tub $\times$ phu- 2 & 1 & 0 & 0 & 0 & 1 & 0 & 0 & 1 & n.t. & 1 \\
\hline $\operatorname{mcd} \times \operatorname{tar}$ & 3 & - & - & 3 & - & - & - & 3 & 0 & 3 \\
\hline \multirow[t]{2}{*}{$(\operatorname{mcd} \times \operatorname{tar}) \times \mathrm{ktz}$} & 2 & - & - & 2 & - & - & - & n.t. & 0 & 2 \\
\hline & - & - & 1 & - & - & - & 1 & n.t. & 0 & 0 \\
\hline nan $\times$ phu- 1 & 7 & - & - & - & - & - & 7 & 7 & 0 & n.t. \\
\hline \multirow[t]{2}{*}{ Aurora $\times$ rzc } & - & 1 & 0 & - & 1 & - & 0 & 1 & 0 & n.t. \\
\hline & 1 & - & - & - & - & 1 & - & 1 & 0 & n.t. \\
\hline \multicolumn{11}{|c|}{ Controls in biological tests } \\
\hline grr & 5 & - & - & & & & & & & \\
\hline Brasla & - & - & 5 & & & & & & & \\
\hline Brasla & & & & 5 & - & - & - & & & \\
\hline Mutagenagrie & & & & - & - & - & 5 & & & \\
\hline
\end{tabular}

\footnotetext{
1) $\mathrm{R}=$ resistant, $\mathrm{MR}=$ moderately resistant, $\mathrm{MS}=$ moderately susceptible, $\mathrm{S}=$ susceptible;

2) n.t., not tested
}

Aurora $\times$ rzc, one was late blight resistant but infected by nematode and the other expressed moderate resistance to both late blight and nematode.

Molecular tests. The marker CP113 was not polymorphic and in all plants amplified an allele linked to the gene $H 1$ providing resistance to $G$. rostochiensis of pathotype Ro1, including all phenotype susceptible plants of grr $\times$ adg. All plants of hybrid grr $\times$ adg were also tested with marker of gene Grol-4 and none were positive. DNA marker tags for gene $H 1$ were found in all 20 plants of the hybrid nan $\times$ phu population. All progenies of hybrids grr $\times$ B.d.R5, $(\operatorname{grr} \times$ adg $\times$ Omega, nan $\times($ tbr $\times$ phu $)$, and Aurora $\times($ tbr $\times$ phu $)$ also amplified the gene $H 1$ resistance allele (Table 2). PCR tests detected marker Grol of gene Grol-4 in resistant plant material with an exception of three clones of hybrid grr $\times$ B.d. R5, where three susceptible clones were positive for this marker. Marker Gro1 was amplified in 11 resistant clones of grr $\times$ B.d. R5, in one of two clones of ( grr $\times$ adg) $\times$ Omega, in one of 10 clones of hybrid nan $\times($ tbr $\times$ phu- 2$)$, in the one tested clone of hybrid tbr $\times$ phu-2, in each of three tested clones of mcd $\times$ tar and in two of three clones of hybrid $(\operatorname{mcd} \times \operatorname{tar}) \times \mathrm{ktz}$ (Table 2). Molecular screening of ktz parental accessions showed presence of marker Gro1 in three of four clones (data are not shown in table).

In PCR tests using the marker 57R linked to the $H 1$ gene locus confirmed the presence of the Hlgene allele only in resistant clones of hybrid nan $\times \mathrm{cv}$. Aurora. This marker (adopted from Skupinova (2002)) did not amplify gene $H 1$ fragments in hybrids grr $\times$ adg, in susceptible clones of Aurora $\times($ tub $\times$ phu- 2$)$, in plants of nan $\times$ phu- 1 , mcd $\times \operatorname{tar}$ and $(\operatorname{mcd} \times \operatorname{tar}) \times \mathrm{ktz}$.

The results revealed a contradiction between the data of biological and molecular tests. Marker CP113 was detected in all clones from 24 plant populations of hybrid grr $\times$ adg that was susceptible as determined by biological tests. None of the plants of this population amplified the resistant allele of 
marker 57R. The resistance allele of marker CP113 was detected in all 15 tested clones of hybrid $\mathrm{AU} \times(\mathrm{tbr} \times \mathrm{phu}-2)$ while only six expressed phenotypic resistance. In susceptible plants of hybrids (grr $\times$ adg) $\times \mathrm{cv}$. Omega, nan $\times($ tub $\times$ phu-2), nan $\times$ Aurora and nan $\times$ phu-1, the resistance allele of marker CP113 was amplified. In nematode moderately resistant and moderately susceptible clones of hybrid AU $\times$ rcz, the $H 1$ gene resistant allele was detected only using marker C113 and there was no amplification of marker 57R. Resistance allele of gene Grol-4 was detected only in cases where clones expressed resistance in bioassays. It was not amplified in susceptible clones with the exception of three plants of hybrid grr $\times$ B.d. $R 5$ (Table 2). Resistance conferred by Gro1-4 gene was frequently detected in hybrids derived from the South-American potato species $S$. phureja, S. kutrzianum, S. microdontum and S. tarijense.

Combined resistance to late blight and nematode in the current evaluation was found in individual clones of hybrids: nan $\times$ cv. Aurora, nan $\times($ tub $\times$ phu 2$)$, tub $\times$ phu- $2, \mathrm{cv}$. Aurora $\times($ tbr $\times$ phu-2), Aurora $\times$ rzc, grr $\times$ B.d. R5, $($ grr $\times$ adg $\times$ cv. Omega, mcd $\times$ tar and $(\operatorname{mcd} \times \operatorname{tar}) \times$ ktz. The results showed a contradiction between the data of biological and molecular tests. Resistance allele of marker CP113 was detected in all tested individuals of 10 hybrids while only a part of clones expressed resistance under inoculation.

\section{DISCUSSION}

Wild potato species can be considered as promising plant material to increase durable resistance due to their high polymorphism (Nunziata et al., 2010). Current potato breeding requires the combination of several useful traits into one genotype. Due to high economic losses caused by crop diseases, breeders need to develop varieties combining resistance to two or more pathogens. The search for combined resistance to $G$. rostochiensis and potato late blight is essential due to high yield losses caused by these pathogens.

Marker-assisted selection could represent a useful tool for genetic studies and breeding for resistance to G. rostochiensis (Ortega and Lopez-Vizcon, 2012). Its application for identification of disease resistance in potato breeding programmes can reduce the time required for the selection of resistant parental accessions for crosses. Markers linked to resistance genes of economically important diseases and nematodes are useful tools for potato breeding (Asano and Tamiya, 2016). In recent breeding for combined resistance to nematodes, potato virus $\mathrm{Y}$ and late blight has employed marker assisted selection (López et al., 2015, Milczarek et al., 2017). Asano et al. (2012) evaluated potato varieties and lines by the multiplex PCR method, and 264 of 812 were positive for the $H 1$ marker. Of these, 117 varieties and lines were positive for two markers - H1 and Gpa2. In contrast to these markers, the authors could not find varieties and lines having Grol-4, although evaluated samples included the PCN-resistant S. spegazzinii. This fact emphasises the importance of developing resistant plant material containing Grol-4 (Asano et al., 2012). The resistance genes contained in the narrow genetic background of many potato breeding programmes are already unsuitable to breed novel PCN resistant varieties. The utilisation in breeding of other resistance sources, including those possessing the gene Gro $1-4$, should be promoted to broaden the genetic background of newly developed cultivars.

The locus $H 1$ conferring resistance to G. rostochiensis pathotypes Rol has been mapped to chromosome V (Gebhardt et al., 1993). Skupinova et al. (2002) found a high correlation between the occurrence of the $H 1$ gene and phenotypic resistance to $G$. rostochiensis. According to Skupinová et al., (2002), the $0.76 \mathrm{~kb}$ PCR marker detects only the dominant $H 1$ allele in potato genotypes. Schultz et al., (2012) and Park et al., (2018) reported that the presence of the 57R marker linked to the $H 1$ locus is predictive for PCN resistant phenotypes. Use of MAS in screening for resistance to G. rostochiensis permits early selection of potato clones carrying the $H 1$ gene (Milczarek et al., 2014). Identification of potato cultivars resistant to $G$. rostochiensis by molecular and biological assessments to validate the suitability of marker TG689 has been recently reported (Galek et al., 2011, Milczarek et al., 2011, Felcher et al., 2012).

Resistance to G. rostochiensis has been already introgressed into $S$. tuberosum from some wild Solanum L. species including S. vernei and S. spegazzinii, as well as the South American cultivated species $S$. tuberosum Group Andigena (Ross, 1986; Dale and de Scurrah, 1998). Potato cultivars resistant to the golden cyst nematode (pathotype Ro1) were developed by incorporating the $H 1$ gene from $S$. tuberosum Group Andigena (Ross, 1979; Gebhardt et al., 1993). Despite Andigena being a source of resistance to nematode, Stelter (1971) reported its susceptibility to some G. rostochiensis pathotypes. Several cultivars were developed in the Netherlands using germplasm of the nematode resistance species S. vernei (Mulder and van der Wal, 1997). Interspecific hybrids included in this study were obtained from crosses with wild Solanum species, which were not evaluated in previous studies. Results of our study showed the low percentage of nematode resistant clones among hybrids obtained in crosses with late blight resistant CentralAmerican species.

The habitats of potato species influence plant potential to resist diseases and pests due to long term selection under climatic conditions favourable for the pathogen (Hawkes and Hierting, 1989). Initial evaluation of Solanum germplasm showed S. tuberosum Group Andigena and S. vernei as the sources of resistance to $G$. rostochiensis (Ellenby, 1948, 1952, 1954). Dunnett (1960) was also one of the first to evaluate the large gene pool of tuber-bearing Solanum species, and determined useful traits for breeding purposes, including resistance to $G$. rostochiensis among the Bolivian species $S$. microdontum and S. megistacrobolum. Castelli et al. (2003) reported resistance to nematode found in Bolivian species $S$. berthaultii, $S$. microdontum as well as in $S$. bukasovii - a species partially distributed in Bolivia. Gene $H 1$ conferring resistance to pathotype Ro1 was found in the accessions of S. kurtzianum (Dalamu et al., 2012). These data 
correspond to the results obtained in the current evaluation regarding resistance expressed by hybrids obtained in crosses with Bolivian S. microdontum and S. tarijense and Argentinian species S. kutrzianum with partial tuber resistance to late blight (Zoteyeva et al., 2012). In hybridisation of mcd $\times$ tar with ktz we applied the bulk pollen of the accession ktz kVIR-12488. In the current study three of four tested parental ktz kVIR-12488 showed presence of the Grol-4 gene resistance allele.

Mexican Solanum L. species have also been evaluated for resistance traits. Castelli et al. (2003) reported screening results that showed the susceptibility in S. guerreroense and $S$. stoloniferum accessions and partial resistance in only $20 \%$ of tested S. demissum accessions. Resistance to PCN was found in accessions of $S$. semidemissum and $S$. schenkii, which is closely related to $S$. demissum (Castelli et al., 2003). The current study identified resistance in clones of hybrids between $S$. guerreroense and clone $R 5$ from the set of Black's late blight race differentials, which is a hybrid of $S$. demissum. In the population of this hybrid, the molecular marker linked to Gro 1 gene was amplified in all resistant clones. However, it was also amplified in a few phenotypically susceptible plants. Milczarek et al. (2011) reported examination of two markers linked to the gene GroVI, which failed to discriminate susceptible and resistant clones. The authors explained this phenomenon as occurring due to the highly heterozygous genetic background of tetraploid $S$. tuberosum. In the hybrid grr $\times$ Bd.R5 derived from the hexaploids $S$. guerreroense and $S$. demissum and the tetraploid $S$. tuberosum, marker Gro1 was amplified, but in a few cases was not correlated with phenotypic resistance. The markers of the $H \mathrm{l}$ gene conferring resistance to $G$. rostochiensis pathotype Ro1 and Gro 1-4 revealed differing predictive abilities (Antonova et al., 2016). To obtain reliable molecular screening results for disease resistance of potato clones, several markers should be used.

Plants of hybrids derived from $S$. guerreroense and $S$. neoantipoviczii $(=S$. stoloniferum $)$ were mainly found to be susceptible. In our study, few of the tested clones showed combined phenotypic resistance to $P$. infestans and $G$. rostochiensis. The reason for the difficulty of identification of sources of combined resistance to both pathogens is the different geographical area of distribution of species characterised by resistance to Globodera rostohiensis and those with resistance to late blight. Species resistant to PCN predominate in southern Bolivia and Argentina, where $78 \%$ of accessions were resistant, in contrast to $25 \%$ from Mexico, where highly late blight resistant wild potato germplasm is distributed (Castelli et al., 2003). In field and laboratory assessment, accessions of several Bolivian species were identified as highly or partially foliar late blight resistant (Zoteyeva et al. 2004, Zoteyeva et al. 2012). South-American species Solanum spegazinii, S. famatinae and S. kutrzianum resistant to $G$. rostohiensis with a distribution area in Argentina were also identified as tuber resistant to $P$. infestans (Zoteyeva 2006; 2012). Potato plants combining foliar late blight resistance with resistance to G. rostohiensis can be found among the Bolivian species. It can be assumed that the combination of tuber late blight and nematode resistance can be found among the species with a distribution area in Argentina.

Currently potato breeding aims at expanding diversity of resistance sources to economically important pathogens. This goal is being achieved by using interspecific hybridisation. Wild potato species are mainly characterised by small tuber size and long stolons. Plants with improved agronomic characteristics and high resistance rating occur after backrosses to cultivated potatoes within the populations of interspecific hybrids. The process of hybridisation using plant material included in current evaluation resulted in a number of multispecies hybrids with resistance to late blight and good tuber characteristics (Zoteyeva et al., 2017). In our pre-breeding research the germplasm of $S$. guerreroense, S. neoantipoviczii, S. kurtzianum and $S$. microdontum $\times S$. tarijense were involved. The first hybrid of $S$. guerreroense was obtained in crossing with Swedish variety Superb. This hybrid produced middle size tubers, a part of which had irregular shape and long stolons. The next hybrid progenies obtained through crossing of abovementioned hybrid with $S$. tuberosum breeding clone had short stolons and produced large size tubers of good morphology (Zoteyeva and Carlson-Nilsson, 2013). The hybrid derived from cross between $S$. guerreroense $\times 2 S$. tuberosum and S. kurtzianum kVIR-12488 had a short stolon and produced over 50 regular shape tubers per plant (Zoteyeva, 2018). Interspecific hybrids with detected markers of genes conferring resistance to late blight and Potato Virus Y were obtained using S. neoantipoviczii (Zoteyeva et al., 2017).

The data obtained in our study provided additional information on the resistance to G. rostohiensis (pathotype Ro1) of interspecific potato hybrids derived from crosses with species of differing geographical distribution. Summarising the results from the literature and our own data obtained in current and previous studies, we can conclude that the accessions and interspecific potato hybrid clones with combined resistance to late blight and to $G$. rostohiensis belong mostly to South American species with a distribution area in Bolivia and in Argentina. These species are characterised by presence of haplotype Gro 1-4. Hybrids obtained in crosses with the Mexican species $S$. neoantipoviczii (= S. stoloniferum) from the taxonomic series Longipedicellata Buk. exhibited resistance when derived from combinations with PCN resistant germplasm.

This study verified the good correlation of the markers 57R and Grol with resistance to PCN, but revealed the inconsistency between phenotypic resistance and screening for resistance to $G$. rostohiensis using the marker CP113. The identified interspecific crosses and markers 57R and Gro1 can be further used in potato breeding for backcrossing into elite germplasm. 


\section{ACKNOWLEGMENTS}

We appreciate Dr. Ilze Skrabule for providing the control cultivars and Daiga Vilcanne for help in performing the molecular analyses. This study was partially supported by European Social Fund project: ESF Nr.2009/0218/1DP/ 1.1.1.2.0/APIA/VIAA/099 and by Programme of Fundamental Research of the State Academies of Science (Russian Federation) for 2013-2020 (0662-2019-0004).

\section{REFERENCES}

Antonova, O. Y., Shvachko, N. A., Novikova, L. Y., Shuvalov, O. Y., Kostina, L. I., Klimenko, N. S., Shuvalova, A. R., Gavrilenko,T. A. (2016). Genetic diversity of potato varieties bred in Russia and near-abroad countries based on polymorphism of SSR-loci and markers associated with resistance $R$-genes. Vavilovskii Zhurnal Genetiki $i$ Selektsii $=$ Vavilov Jour nal of Genetics and Breeding, 20 (5), 596-606.

Asano, K., Kobayashi, A., Tsuda, S., Nishinaka, M., Tamiya, S. (2012). DNA marker-assisted evaluation of potato genotypes for potential resistance to potato cyst nematode pathotypes not yet invading into Japan. Breeding Sci., 62 (2), 142-150.

Asano, K., Tamiya, S. (2016). Breeding of pest and disease resistant potato cultivars in Japan by using classical and molecular approaches. JARQ ( $\mathrm{Ja}$ pan Agricult. Res. Quart.), 50, 1-6.

Aversano, R., Ercolano, M. R., Frusciante, L., Monti, L., Bradeen, J. M., Cristinzio, G., Zoina, A., Greco, N., Vitale, S., Carputo, D. (2007). Resistance traits and AFLP characterization of diploid primitive tuber-bearing potatoes, Genet. Res. Crop Evol., 54 (8), 1797-1806.

Bakker, E., Achenbach, U., Bakker, J., van Vliet, J., Peleman, J., Segers, B., van der Heijden, S., van der Linde, P., Graveland, R, Hutten, R., van Eck, H., Coppoolse, E., van der Vossen, E., Bakker, J., Goverse, A. (2004). A high-resolution map of the $H 1$ locus harbouring resistance to the potato cyst nematode Globodera rostochiensis. Theor. Appl. Genet., 109, $146-152$

Bradshaw, J. E., Ramsay, G. (2005). Utilisation of the Commonwealth Potato Collection in potato breeding. Euphytica, 146, 9-19.

Bryan, G. J., McLean, K, Bradshaw, J. E., De Jong, W. S., Phillips, M, Castelli, L, Waugh, R. (2002). Mapping QTLs for resistance to the cyst nematode Globodera pallida derived from the wild potato species Solanum vernei. Theor. Appl. Genet., 105, 68-77.

Castelli, L., Ramsay, G., Bryan, G., Neilson, S.J., Phillips, M. S. (2003). New sources of resistance to the potato cyst nematodes Globodera pallida and G. rostochiensis in the Commonwealth Potato Collection. Euphytica, 129, 377-386

Chimote, V. P., Swarup, K., Chakrabarti S. K., Pattanayak D., Pandey, S. K., Naik, P. S. (2008). Molecular analysis of cytoplasm type in Indian potato varieties. Euphytica, 162, 69-80.

Dalamu, Bhardwaj, V., Umamaheshwari, R., Sharma, R., Kaushik, S. K., Joseph, T. A., Singh B. P., Gebhardt C. (2012). Potato cyst nematode (PCN) resistance: Genes, genotypes and markers - an update. SABRAO, J. Breed. Genet., 44 (2), 202-228.

Dale, M. F. B., de Scurrah M. M. (1998). Breeding for resistance to the potato cyst nematodes Globodera rostochiensis and Globodera pallida. In: Marks, R. J., Brodie, B. B. (eds.). Potato Cyst Nematodes - Biology, Distribution and Control. CAB International, Wallingford, pp. 167-195

Dunnett, J. M. (1960). The role of Solanum vernei Bitt. et Wittm. in breeding for resistance to potato root eelworm (Heterodera rostochiensis Woll.). In: Report of the Scottish Plant Breeding Station, 39-44.

Ellenby, C. (1948). Resistance to the potato-root eelworm. Nature, 162, 704.

Ellenby, C. (1952). Resistance to the potato-root eelworm Heterodera rostochiensis Woll. Nature, 170, 1016.
Ellenby, C. (1954). Tuber forming species and varieties of the genus Solanum tested for resistance to the potato root eelworm Heterodera rostochiensis. Euphytica, 3, 195-202.

Felcher, K. J., Coombs, J. J., Massa, A. N., Hansey, C. N., Hamilton, J. P., Veilleux, R. E., Buell, C., Douches, D. S. (2012). Integration of two diploid potato linkage maps with the potato genome sequence. PLOS ONE, 7 (4), e36347.

Finkers-Tomczak, A., Bakker, E., de Boer, J., van der Vossen, E., Achenback, U., Golas, T., Suryaningrat, S., Bakker, J., Goverse, A. (2011). Comparative sequence analysis of the potato cyst nematode resistnace locus $H 1$ reveals a major lack of co-linearity between three haplotypes in potato (Solanum tuberosum spp.) Theor. Appl. Genet., 122 (3), 595-608.

Flis, B., Hennig, J., Strzelczyk-Żyta, D., Gebhardt, C., Marczewski, W. (2005). The Ry-fsto gene from Solanum stoloniferum for extreme resistant to Potato virus $Y$ maps to potato chromosome XII and is diagnosed by PCR marker GP122718 in PVY resistant potato varieties. Mol. Breed., 15, 95-101.

Fry, W. (2008). Phytophthora infestans: The plant (and R gene) destroyer. Molec. Plant Pathol., 9 (3), 385-402.

Galek, R., Rurek, W., DeJong, W. S., Pietkiewicz, G., Augustyniak, H., Sawicka-Sienkiewicz, E. (2011). Application of DNA markers linked to the potato $H 1$ gene conferring resistance to pathotype Rol of Globodera rostochiensis. J. Appl. Gen., 52, 407-411.

Gebhardt, C., Mugniery, D., Ritter, E., Salamini, F., Bonnel, E. (1993). Identification of RFLP markers closely linked to the $H 1$ gene conferring resistance to Globodera rostochiensis in potato. Theor. Appl. Genet. 85 (5), 541-544.

Gebhardt, C., Bellin, D., Henselewski, H., Lehmann, W., Schwarzfischer, J., Valkonen, J. P. T. (2006). Marker assisted combination of major genes for pathogen resistance in potato. Theor. Appl. Genet. 112, 1458-1464.

Glendinninger, D. R. (1983). Potato introductions and breeding up to the early 20th century. New Phytol., 94, 479-505.

Guha, R. S., Grünwald, N. J. (2014). The plant destroyer genus Phytophthora in the $21^{\text {st }}$ Century. Rev. Plant Pathol., 6, 387-412.

Hawkes, J. G., Hierting, J. P. (1989). The Potatoes of Bolivia - Their Breeding Value and evolutionary Relationships. Clarendon Press, Oxford. 472 pp.

Holgado, R., Magnusson, C. (2010). Management of PCN (Globodera spp.) populations under Norwegian conditions. Aspects Appl. Biol., 103, 83-92.

Lopez, M., Riegel, R., Lizana, C., Behn, A. (2015). Identification of virus and nematode resistance genes in the Chilota Potato Genebank of the Universidad Austral de Chile. Chilean J. Agric. Res., 75 (3), 320-327.

Marks, R. J., Brodie, B. B. (1998). Potato cyst nematodes — An international pest complex. In: Marks R. J., Brodie B. B. (eds.). Potato Cyst Nematodes - Biology, Distribution and Control. CAB International, Wallingford, pp. 1-4.

Milczarek, D., Flis, B., Pizetakiewicz, A. (2011). Suitability of molecular markers for selection of potatoes resistance to Globodera spp. Amer. J. Potato Res., 88, 245-255.

Milczarek, D., Przetakiewicz, A., Kamiński, P., Flis, B. (2014). Early selection of potato clones with the $H 1$ resistance gene - the relation of nematode resistance to quality characteristics. Czech J. Genet. Plant Breed., 50 $278-284$.

Milczarek, D., Plich, J., Tatarowska, B., Flis, B. (2017). Early selection of potato clones with resistance genes: The relationship between combined resistance and agronomical characteristics. Breed Sci., 67 (4), 416-420.

Mulder, A., van der Wal, A. F. (1997). Relationship between potato cyst nematodes and their principal host. A literature review Pot. Res., 40, $317-326$.

Nunziata, A., Ruggieri, V., Greco, N., Frusciante, L., Barone A. (2010). Genetic diversity within wild potato species (Solanum spp.) Revealed by AFLP and SCAR Markers. Amer. J. Plant Sci., 1, 95-103. 
Ortega, F., Lopez-Vizcon, C. (2012). Application of molecular marker-assisted selection (MAS) for disease resistance in a practical potato breeding programme. Pot. Res., 55, 1-13.

Paal, J., Henselewski, H., Muth, J., Meksem, K., Menendez, C. M., Salamini, F., Ballvora, A., Gebhard, C. (2004). Molecular cloning of the potato Grol-4 gene conferring resistance to pathotype Ro1 of the root cyst nematode Globodera rostochiensis, based on a candidate gene approach. Plant J., 38 (2), 285-297.

Park, J., Yang, H., De Jong, W. S., Wang, X. (2018). An evaluation of two H1-linked markers and their suitability for Selecting Globodera rostochiensis. Resistant potatoes in the New York Breeding Program. Amer. J. Potato Res., 95, 170-177.

Ross, H. (1986). Potato breeding: Problems and perspectives. In: W. Horn, G. Robbelen (eds.). J. Plant Breed. Supplement, 13, 82-86.

Schultz, L., Cogan, N. O. I., Mclean, K., Dale, F. B., Bryan, G. J., Forster, J. W., Slater, A. T. (2012). Evaluation and implementation of a potential diagnostic molecular marker for $\mathrm{H} 1$-conferred potato cyst nematode resistance in potato (Solanum tuberosum L.). Plant Breed., 131, 315-321.

Sevilla, R., Ortiz, R. (2010). The economic impact of the research of the CGIAR in Peru [El impacto económico de la investigación del CGIAR en el Peru]. Agrum, 33, 52-55

Skupinová, S., Vejl, P., Sedlák, P., Domkáøova, J. (2002). Segregation of DNA markers of potato (Solanum tuberosum ssp. tuberosum L.) resistant against Ro1 pathotype Globodera rostochiensis in selected F1 progeny. Rostlinní Vżroba, 45, 480-485.

Stelter, H. (1971). Zur Methodik der Nematodånresis — tenzprüfung und zur Sicherung der Ergebnisse, Biol. Zbl., 90 (3), 357-363.

Sudha, R., Venkatasalam, E. P., Bairwa, A., Bhardwaj, V., Dalamu, Sharma, R. (2016). Identification of potato cyst nematode resistant genotypes using molecular markers. Scientia Horticulturae, 198, 21-26.

Yu, K., Park, S. J., Poysa, V. (2000). Marker-assisted selection of common beans for resistance to common bacterial blight: Efficacy and economics. Plant Breed., 119, 411-415.

Wulff, E., Torres, S., Vigil, E. (2002). Protocol for DNA extraction from potato tubers. Plant Mol. Biol. Rep., 20, 187-187.
Zarzycka, H. (2001). Evaluation of resistance to Phytophthora infestans in detached leaflet assay. Monografie i Rozprawy Naukowe 10b/2001, Radzików, IHAR, 75-77.

Zoteyeva, N. M., Chrzanowska, M., Evstratova, L. P, Fasulati, S. R., Yusupov, T. (2004). Resistance of wild potato species accessions to diseases and pests. [Зотеева Н.М., Хжановска М., Евстратова Л.П., Фасулати С.P., Юсупов, Т. Устойчивость образцов диких видов картофеля к болезням и вредителям]. In: Catalogue of VIR's Collection, 186 pp. (in Russian).

Zoteyeva, N. M., Carlson-Nilsson, U. B. (2013). Pre-breeding focused on late blight resistance utilizing a diverse potato germplasm. In: Proceedings of the European Plant Genetic Resources Conference "Prebreeding-fishing in the gene pool", NordGen, SLU, Alnarp, Sweden, 11-13 June 2013. R. Ortiz (ed.), p. 148.

Zoteyeva, N. (2006). Frequency of genotypes with tuber resistance to Phy tophthora infestans in wild potato species. In: Proceeding of the Ninth Workshop of an European network for development of an integrated control strategy of potato late blight. Tallinn, Estonia, 19-23 October 2005. Westerdijk, C. E., Schepers, H. T. A. M. (eds.).Wageningen, NL., pp. 281-290.

Zoteyeva, N., Chrzanowska, M., Flis, B., Zimnoch-Guzowska, E. (2012). Resistance to pathogens of the potato accessions from the collection of N. I. Vavilov Institute of Plant Industry (VIR). Amer. J. Potato Res., 89, 277-293.

Zoteyeva, N., Mezaka, I., Vilcāne, D., Carlson-Nilsson, U., Skrabule, I., Rostoks, N. (2014). Assessment of genes $R 1$ and $R 3$ conferring resistance to late blight and of gene Rysto conferring resistance to potato virus $\mathrm{Y}$ in two wild species accessions and their hybrid progenies. Proc. Latvian Acad. Sci., Section B, 68 (3/4), 133-141.

Zoteyeva, N. M., Antonova, O. Yu., Klimenko, N. S., Apalikova, O. V., Carlson-Nilsson, U., Karabitsina, Yu. I., Ukhatova, Yu. V., Gavrilenko, T. A. (2017). Facilitation of introgressive hybridization of wild polyploid Mexican potato species using DNA markers of $R$ genes and of different cytoplasmic types [Зотеева, Н. М., Антонова, О. Ю., Клименко, Н. С., Апаликова, О. В., Carlson-Nilsson U., Карабицина, Ю. И., Ухатова, Ю. В., Гавриленко, Т. А. Использование молекулярных маркеров $\boldsymbol{r}$ генов и типов цитоплазмы при интрогрессивной гибридизации диких полиплоидных мексиканских видов картофеля]. Sel'skokhozyaistvennaya biologiya [Agricultural Biology], 52 (5), 964-975.

Zoteyeva, N. M. (2018). Foliar and tuber resistance to late blight of interspecific potato hybrids derived from Solanum kurtzianum Bitt. et Wittm. Plant Protect. News, 95 (1), 21-25 (in Russian).

Received 11 December 2018

Accepted in the final form 12 October 2019

\section{KARTUPELUU STARPSUGU HIBRĪDU AR IZTURĪBU PRET LAKSTU PUVI (PHYTOPHTHORA INFESTANS) UN NEMATODI (GLOBODERA ROSTOCHIENSIS) IDENTIFICĒŠANA}

Lakstu puve (Phytophthora infestans) un zeltītā kartupeḷu cistu nematode (Globodera rostochiensis) ir kartupeḷu patogēni, kuri var ievērojami samazināt kartupeḷu ražu. Šajā pētījumā kartupeḷu starpsugu hibrīdi izmantoti kā rezistences avots, lai iegūtu augus ar izturību pret abiem ekonomiski nozīmīgajiem kartupeḷu patogēniem: lakstu puvi un zeltīto kartupeḷu cistu nematodi. Pētījuma mērkis bija identificēt hibrīdus ar izturību pret abiem patogēniem un pārbaudīt vairāku molekulāro markieru piemērotību zeltītās cistu nematodes patotipa Ro1 izturīgu augu izlasei. Deviṇdesmit divi kloni no vienpadsmit kartupeḷu starpsugu hibrīdiem, kas iegūti, krustojot kultivēto $S$. tuberosum grupu tuberosum, S. tuberosum grupu Andigena, S. tuberosum grupu Phureja un savvalas S. guerreroense, S. microdintum, S. kurtzianum, S. neoantipoviczii un S. tarijense kartupeḷu sugas, tika pārbaudīti, inokulējot un ar molekulārajiem markieriem. Ar inokulēšanas metodi zeltītās cistu nematodes izturība tika identificēta deviṇu hibrīdu pēcnācējos. Ar inokolāciju iegūtie rezultāti lielā mērā sakrita ar molekulāro marḳieru noteikto rezistences statusu, izmantojot marḳierus, kas saistīti ar H1 gēnu (markiieris 57R) un Grol-4 gēnu (markieris Gro1). AR H1 gēnu saistîtais markieris CP113 nebija polimorfs un nespēja noteikt rezistences statusu. Lakstu puves un zeltītās kartupeḷu cistu nematodes izturība tika identificēta hibrīdos, kas iegūti, krustojot $S$. microdontum, S. tarijense un $S$. phureja sugu augus, kā arī $S$. guerreroense un Bleka $P$. infestans rasu diferenciāḷos, kas nēsā gēnu $R-5$. 